\begin{tabular}{cc|c}
\hline Tar. Bil. Der. & Tarm Bilimleri Dergisi & Journal of Agricultural Sciences \\
& $\begin{array}{c}\text { Dergi web sayfası: } \\
\text { www.agri.ankara.edu.tr/dergi }\end{array}$ & Journal homepage: \\
& www.agri.ankara.edu.tr/journal
\end{tabular}

\title{
Inheritance of Indehiscent Capsule Character, Heritability and Genetic Advance Analyses in the Segregation Generations of Dehiscent $x$ Indehiscent Capsules in Sesame
}

\author{
Engin YOL ${ }^{\mathrm{a}}$, Bulent UZUN ${ }^{\mathrm{a}}$ \\ ${ }^{a}$ Akdeniz University, Faculty of Agriculture, Department of Field Crops, Antalya, TURKEY
}

\section{ARTICLE INFO}

Research Article

DOI: 10.15832 /ankutbd.539005

Corresponding Author: Bulent UZUN, E-mail: bulentuzun@akdeniz.edu.tr, Tel: +90 (242) 3102424

Received: 06 December 2017, Received in Revised Form: 06 March 2018, Accepted: 20 March 2018

\begin{abstract}
The investigation was made to estimate heritability and genetic advance and thus understand the genetic behavior of indehiscent capsule character in sesame with the field experiments during three consecutive years. Muganli-57 ( $(+)$ parent with dehiscent capsule was crossed with ACS 344 (§), an introduction material, which had indehiscent capsule character. The results in the $\mathrm{F}_{1}$ generation indicated that dehiscent capsule character was dominant over indehiscent capsule. In $\mathrm{F}_{2}, 3: 1$ segregation ratio was monitored and further confirmed in $\mathrm{F}_{3}$ showing indehiscent capsule character was controlled by a single recessive gene. Heritability was estimated by parent-offspring regression and the data were collected in $\mathrm{F}_{1}, \mathrm{~F}_{2}$ and $\mathrm{F}_{3}$ generations derived from the cross between dehiscent and indehiscent capsule types. Heritability estimates in narrow sense for number of branches, number of capsules per plant, 1000 seed weight and seed yield were low in indehiscent capsule types of $\mathrm{F}_{2}$. Genetic advance had also low values except for number of branches $(30.79 \%)$. Whilst low values obtained for indehiscent capsule, dehiscent capsule types in $\mathrm{F}_{2}$ indicated high heritability for the characters studied (70.52-92.84\%). Stem height to the first capsule and plant height were of high heritabilities in both capsule types of $\mathrm{F}_{2}$ and $\mathrm{F}_{3}$. Although indehiscent capsule types had low means and heritabilities due to pleiotropic effects, mutant cross had heterotic effect on dehiscent types for all the characters. This positive shift could be explained by additive gene effect and this information presented in this investigation was therefore highly beneficial for the genetic improvement of sesame and reaching to high yielding types. This research also provides an example that bad parent may have a good progeny.

Keywords: Capsule shattering; Genetic parameters; Mutation; Pleiotropy
\end{abstract}

(C) Ankara Üniversitesi Ziraat Fakültesi

\section{Introduction}

Sesame (Sesamum indicum L.) is one of the world's important oilseed crops and has been used for food and animal feeding in the form of seed, seed oil and meal (Hahm et al 2009). Sesame oil includes antioxidant lignans such as sesamin and sesamolin which have lots of health benefits. Especially sesamin has been linked with prevention of hyperlipidemia, hypertension, and carcinogenesis (Harikumar et al 2010). In addition, sesame has agricultural advantages: it grows well tropic, subtropic and Mediterranean climates, can grow on only soil moisture without rainfall or irrigation (Ashri 2007) and can be used as a second crop which is 
important for sustainable farming. Despite such desirable characteristics, sesame production suffers from certain major causes of low seed yields include capsule shattering, indeterminate growth habit, late maturity, low adaptation ability.

Normally, the seed-bearing capsule of sesame shatters at harvest. This wildish character is the most problematic issue in sesame farming because it causes seed losses at harvest which can be very high, up to $50 \%$ (Weiss 1971). This unimproved character also makes the crop unsuitable for mechanized harvesting (Langham \& Wiemers 2002) and consequently restricts its commercial potential by limiting the growing areas to countries that have no access to cheap labor (Uzun et al 2003). Therefore non-shattering capsule genotypes are needed for mechanized harvesting of sesame.

Although an indehiscent mutation that held all of sesame seed was first discovered by Langham (1946), the majority of the world's sesame (probably over 99\%) is shattering, and most of the harvest is manual (Langham 2001). The most important reason was the pleiotropic effects of the mutation including cupped leaves, short seed pods, twisted stems and low seed yield (Wongyai et al 2001). These unwanted side effects restrict non-shattering sesame usage and crossing with cultivars which have different genetic backgrounds should be beneficial to remove the undesirable side-effects (Uzun et al 2004). Because, selected parents from divergent origins have potential to present beneficial traits (Ashri 1998). Even though non-shattering sesame has been used as a parent in breeding programs, there is no report about heritability and genetic advance on yield and yield components in hybridization studies. To understand genetic behaviors of characters genetic parameters would be helpful (Majidi et al 2009). This type data is important for identification of agronomic potential of genotypes. Such data is usefully subjugated in articulating efficient selection program for synthesis and development of cultivars with desirable characters having genetic base (Khan et al 2010). From this perspective, the objectives of the current study were to evaluate the genetic parameters (heritability, inheritance and genetic advance) in indehiscent capsule type sesame, its cross with dehiscent capsule type sesame and exhibit their breeding potential.

\section{Material and Methods}

\subsection{Experimental area}

The field experiments were conducted at the West Mediterranean Agricultural Research Institute's fields of Antalya ( $36^{\circ} 52^{\prime}$ N. $30^{\circ} 50^{\prime}$ E. 15 m elevation). Antalya has coastline to Mediterranean Sea and it has $1060 \mathrm{~mm}$ annual average precipitation and 18 ${ }^{\circ} \mathrm{C}$ annual average temperature (TSMS 2010).

\subsection{Plant materials}

Indehiscent capsule sesame (PI 599446) was kindly provided by USDA, ARS, Georgia, USA and deposited in our collection with the code of ACS 344. Muganli-57 with dehiscent capsule ( $(+)$ was crossed with ACS $344(\delta)$ in 2008. $\mathrm{F}_{1}$ s were selfed in the growing season of 2009 and $F_{2}$ and $F_{3}$ populations were developed in the years of 2010 and 2011.

\subsection{Genetic study}

Parents, $\mathrm{F}_{1} \mathrm{~s}, \mathrm{~F}_{2} \mathrm{~s}$ and $\mathrm{F}_{3} \mathrm{~s}$ were grown in $70 \mathrm{~cm}$ row and plant to plant within a row of $10 \mathrm{~cm}$. Fertilizer was applied at rates of $60 \mathrm{~kg} \mathrm{~N}, 60 \mathrm{~kg} \mathrm{P}_{2} \mathrm{O}_{5}$ and $60 \mathrm{~kg} \mathrm{~K} \mathrm{O}_{2}$ per hectare prior to sowing $\mathrm{F}_{1}, \mathrm{~F}_{2}$ and $\mathrm{F}_{3}$ generations. 56 seeds from hybridization of Muganli-57 and ACS 344 were used to produce $\mathrm{F}_{1}$ plants. In $\mathrm{F}_{2}$ generation, dehiscent capsule and indehiscent capsule plants were grown with the numbers of 803 and 254, respectively. Single dehiscent and indehiscent capsule plants in $F_{2}$ and $\mathrm{F}_{3}$ were selected and compared with previous generations for heritability. The characters of stem length to the first capsule (SLFC), plant height (PH), number of branches (NB), number of capsules per plant (NCP), number of seeds per capsules (NSC), 1000 seed weight (TSW) and seed yield (SY) were used for the assessments (IPGRI \& NBPGR 2004).

\subsection{Statistical analysis for inheritance}

Statistical analysis for inheritance was conducted according to Steel \& Torrie (1980). Parent offspring 
method was used for heritability estimates in narrow sense according to Smith \& Kinman (1965) with the formula;

$\mathrm{h}_{\mathrm{rg}} 2=\mathrm{b} / 2 \mathrm{r}_{\mathrm{op}}$

Where; $b$ is regression coefficient and $r_{\text {op }}$ is relationship of parent-offspring.

$20 \%$ selection intensity was applied for the genetic advance calculations. Genetic advance was conducted using the following formula;

$\mathrm{GA}=\mathrm{K}\left(\mathrm{S}_{\mathrm{ph}}\right)(\mathrm{H})$

Where; $\mathrm{K}$ is a constant which at a selection intensity of $20 \%$ is about $1.40 ; \mathrm{S}_{\mathrm{ph}}$ is the phenotypic standard deviation $\left(\sqrt{V_{\mathrm{ph}}}\right) ; \mathrm{H}$ is the heritability ratio.

\section{Results}

\subsection{Heritability and genetic advance}

Heritability estimates in narrow sense of dehiscent $\mathrm{x}$ indehiscent capsule cross were calculated for seven quantitative characters (Table 1). Heritability and genetic advance of dehiscent and indehiscent capsule types were estimated separately and thus the plants in $\mathrm{F}_{2}$ were classified as dehiscent and indehiscent capsule types. The highest heritability was obtained for SLFC (78.3\%) in indehiscent capsule types in $\mathrm{F}_{2}$. PH indicated latter the highest heritability (74.4\%). Following to these characters, NB, NCP, NSC and TSW showed low heritability ranged from $54.5 \%$ to $44.0 \%$ (Table 1). On the other hand the lowest heritability was observed for SY (22.2\%). Heritability estimates for dehiscent capsule types was higher than those of indehiscent capsule in $\mathrm{F}_{2}$ generation for all characters except for SLFC (Table 1). Narrow sense heritability $\left(\mathrm{h}^{2}\right)$ was the highest (92.8\%) for NCP, followed by NSC $(90.1 \%)$ for dehiscent capsule types in $\mathrm{F}_{2}$. Similar high heritability trends were observed for NB $(87.9 \%)$ and $\mathrm{PH}(86.0 \%)$. However three characters, SLFC, TSW and SY, had heritability under $80 \%$, particularly SY showed the lowest heritability $(70.5 \%)$ for dehiscent capsule types in $\mathrm{F}_{2}$.

Estimates of genetic advance (GA) ranged from $2.6 \%$ to $30.8 \%$ for indehiscent capsules in $\mathrm{F}_{2}$. Generally, SLFC, PH, NCP and SY depicted GA values lower than $10 \%$. In contrast, TSW showed relatively high GA estimation ( $>15 \%)$. GA valuation for dehiscent capsule types was much higher than those of indehiscent capsule in $\mathrm{F}_{2}$ (Table 1). The characters of NB, TSW, SY, and NCP showed appreciable GA estimates with values of $49.7 \%, 28.4 \%, 26.0 \%$ and $12.4 \%$, respectively. The remaining three characters,

Table 1- Heritability $\left(h^{2}\right)$ of by parent-offspring regression and standard errors of dehiscent capsule $x$ indehiscent capsule cross and its genetic advance (GA)

\begin{tabular}{|c|c|c|c|c|c|c|c|c|}
\hline \multirow[b]{3}{*}{ Traits } & \multicolumn{3}{|l|}{$F_{1}$ to $F_{2}$} & \multicolumn{5}{|c|}{$F_{2}$ to $F_{3}(I C T$ to ICT and DCT to DCT) } \\
\hline & $h^{2}(\%)$ & $G A(\%)$ & $h^{2}(\%)$ & $G A(\%)$ & $h^{2}(\%)$ & $G A(\%)$ & $h^{2}(\%)$ & $G A(\%)$ \\
\hline & $\begin{array}{l}\text { Indehiscent } \\
\text { capsule } \\
\text { types (ICT) }\end{array}$ & $\begin{array}{r}\text { Indehiscent } \\
\text { capsule } \\
\text { types }\end{array}$ & $\begin{array}{r}\text { Dehiscent } \\
\text { capsule } \\
\text { types }(D C T)\end{array}$ & $\begin{array}{r}\text { Dehiscent } \\
\text { capsule } \\
\text { types }\end{array}$ & $\begin{array}{r}\text { Indehiscent } \\
\text { capsule } \\
\text { types }\end{array}$ & $\begin{array}{r}\text { Indehiscent } \\
\text { capsule } \\
\text { types }\end{array}$ & $\begin{array}{r}\text { Dehiscent } \\
\text { capsule } \\
\text { types }\end{array}$ & $\begin{array}{r}\text { Dehiscent } \\
\text { capsule } \\
\text { types }\end{array}$ \\
\hline$\overline{\text { SLFC }}$ & $78.3 \pm 0.3$ & 8.9 & $78.2 \pm 0.3$ & 8.9 & $75.3 \pm 0.1$ & 10.9 & $82.4 \pm 0.5$ & 8.7 \\
\hline $\mathrm{PH}$ & $74.4 \pm 0.7$ & 3.7 & $86.0 \pm 0.4$ & 4.3 & $89.3 \pm 0.9$ & 34.6 & $87.8 \pm 0.3$ & 17.6 \\
\hline NB & $54.5 \pm 0.3$ & 30.8 & $87.9 \pm 0.1$ & 49.7 & $83.3 \pm 0.2$ & 1.3 & $83.3 \pm 0.2$ & 1.2 \\
\hline $\mathrm{NCP}$ & $46.4 \pm 0.2$ & 6.2 & $92.8 \pm 0.5$ & 12.4 & $92.8 \pm 0.1$ & 25.6 & $90.4 \pm 0.1$ & 13.0 \\
\hline NSC & $50.0 \pm 0.3$ & 2.6 & $90.1 \pm 0.5$ & 4.7 & $91.7 \pm 0.1$ & 5.3 & $96.1 \pm 0.1$ & 5.2 \\
\hline TSW & $44.0 \pm 0.1$ & 16.3 & $76.8 \pm 0.2$ & 28.4 & $62.5 \pm 0.1$ & 0.1 & $71.2 \pm 1.2$ & 0.2 \\
\hline SY & $22.2 \pm 0.1$ & 8.2 & $70.5 \pm 0.8$ & 26.0 & $63.1 \pm 0.6$ & 0.2 & $69.7 \pm 0.6$ & 2.2 \\
\hline
\end{tabular}

ICT is stand for indehiscent capsule types; DCT is stand for dehiscent capsule types. SLFC is stand for stem length to the first capsule; $\mathrm{PH}$ is stand for plant height; NB is stand for number of branches; NCP is stand for number of capsules per plant; NSC is stand for number of seeds per capsules; TSW is stand for 1000 seed weight; SY is stand for seed yield 
SLFC, NSC and PH, depicted genetic advance lower than $10 \%$. Heritability and GA of dehiscent and indehiscent types of sesame were also calculated in $F_{3}$ generation to observe genetic stability of the characters (Table 1). In indehiscent capsule types, the highest heritability was estimated for NCP $(92.8 \%)$ which was followed by NSC (91.7\%), PH (89.3\%) and NB $(83.3 \%)$ as higher heritability. Lower heritability was observed in the characters of SY (63.1\%) and TSW (62.5\%). Among the characters, GA expected from selection of the progenies was the highest for PH (34.6\%) and the lowest for TSW $(0.1 \%)$. Higher heritability estimates was calculated in dehiscent capsule types for the characters of SLFC, $\mathrm{PH}$ and NSC characters in $\mathrm{F}_{3}$ compared to $\mathrm{F}_{2}$. The maximum heritability estimate was for NSC (96.1\%) and the minimum was for SY $(69.7 \%)$ in dehiscent capsule types. Across these characters, NCP and PH showed relatively high heritability values $(90.4 \%$ and $87.8 \%$, respectively).

Mean values of dehiscent capsule plants in $\mathrm{F}_{2}$ were higher than parental lines for all characters (Table 2). However indehiscent capsule plants in
$\mathrm{F}_{2}$ had lower values than the parent, ACS 344 for $\mathrm{NB}, \mathrm{NCP}, \mathrm{NSC}$ and TSW. In dehiscent $\mathrm{F}_{3}$ progenies, the characters of NSC, NCP and SY had the highest mean values compared to $\mathrm{F}_{2} \mathrm{~s}$ and $\mathrm{F}_{3} \mathrm{~s}$ indehiscent types, $\mathrm{F}_{1} \mathrm{~s}$ and both parents. The characters of $\mathrm{PH}$, NCP and NB showed higher means for indehiscent progenies in $\mathrm{F}_{3}$ than $\mathrm{F}_{2}$ (Table 2).

\subsection{Inheritance}

Following to Muganli-57 (ㅇ) x ACS 344 (ふ) cross, all the $F_{1}$ filials had dehiscent capsules. In $\mathrm{F}_{2}$, segregation for dehiscent to indehiscent capsule was 803 to 254 (Table 3). Chi-square value showed a good fit for a monogenic inheritance with the $F_{2}$ phenotypic ratio of $3: 1$. In $F_{3}$, dehiscent and indehiscent capsule type plants obtained from $\mathrm{F}_{2}$ progenies were assessed separately. Totally, 165 plants originating from 5 indehiscent $\mathrm{F}_{2}$ plants indicated indehiscent capsule type and there is no dehiscent capsule type segregation in $\mathrm{F}_{3}$ (Table 4). Similarly dehiscent capsule type $\mathrm{F}_{2}$ plants were advanced to $F_{3}$ separately and of $192 F_{3}$ plants (offspring 1, 2, 4, 5, and 8) showed dehiscent capsule

Table 2- Means and standard errors of the parental lines, $F_{1}, F_{2}$ and $F_{3}$ generations for seed yield and yield components

\begin{tabular}{lllrrrrr}
\hline \multirow{2}{*}{ Characters } & Parental line & \multicolumn{7}{c}{ Muganli-57 $x$ ACS 344 } \\
\cline { 2 - 7 } & Muganli-57 & ACS 344 & $F_{l}$ & $F_{2-i d}$ & $F_{2-I D}$ & $F_{3-i d}$ & $F_{3-I D}$ \\
\hline SLFC $(\mathrm{cm})$ & $52.0 \pm 4.9$ & $52.0 \pm 4.9$ & $42.2 \pm 3.1$ & $57.0 \pm 5.3$ & $58.0 \pm 3.3$ & $41.0 \pm 4.6$ & $57.0 \pm 3.4$ \\
PH $(\mathrm{cm})$ & $127.0 \pm 8.9$ & $86.0 \pm 2.4$ & $111.6 \pm 3.7$ & $157.0 \pm 7.8$ & $142.9 \pm 5.0$ & $162.8 \pm 6.3$ & $146.0 \pm 6.6$ \\
NB & $3.8 \pm 0.2$ & $3.2 \pm 0.2$ & $3.8 \pm 0.4$ & $3.7 \pm 0.5$ & $4.6 \pm 0.3$ & $7.2 \pm 0.5$ & $6.0 \pm 0.5$ \\
NCP & $56.0 \pm 1.0$ & $48.0 \pm 3.0$ & $69.6 \pm 4.7$ & $49.5 \pm 6.9$ & $82.6 \pm 4.7$ & $83.2 \pm 8.8$ & $97.2 \pm 4.6$ \\
NSC & $77.6 \pm 0.7$ & $66.8 \pm 1.5$ & $74.8 \pm 1.5$ & $68.8 \pm 1.3$ & $78.2 \pm 1.5$ & $70.4 \pm 1.8$ & $81.6 \pm 1.7$ \\
TSW (g) & $3.04 \pm 0.1$ & $2.06 \pm 0.1$ & $3.2 \pm 0.1$ & $2.7 \pm 0.1$ & $3.4 \pm 0.1$ & $2.6 \pm 0.1$ & $3.4 \pm 0.1$ \\
SY $(\mathrm{g})$ & $5.91 \pm 1.9$ & $1.24 \pm 0.1$ & $6.74 \pm 1.4$ & $1.2 \pm 0.2$ & $12.3 \pm 3.4$ & $2.2 \pm 0.2$ & $14.4 \pm 2.0$ \\
\hline
\end{tabular}

Muganli-57 is dehiscent capsule genotype, ACS 344 is indehiscent capsule genotype. $\mathrm{F}_{2 \text {-id }}$ is indehiscent capsule genotypes in $\mathrm{F}_{2}, \mathrm{~F}_{2-\mathrm{ID}}$ is dehiscent capsule genotypes in $\mathrm{F}_{2} . \mathrm{F}_{3 \text {-id }}$ is indehiscent capsule genotypes in $\mathrm{F}_{3}, \mathrm{~F}_{3 \text {-ID }}$ is dehiscent genotypes in $\mathrm{F}_{3}$. SLFC is stand or stem length to the first capsule; PH is stand for plant height; NB is stand for number of branches; NCP is stand for number of capsules

Table 3- Segregation ratio of dehiscent and indehiscent characters of sesame in $\mathbf{F}_{2}$

\begin{tabular}{llllllll}
\hline Cross & Experimental & Theoretical & $\chi^{2}$ & $P$ & Ratio \\
\hline & $\begin{array}{l}\text { Dehiscent } \\
\text { capsule }\end{array}$ & $\begin{array}{l}\text { Indehiscent } \\
\text { capsule }\end{array}$ & $\begin{array}{l}\text { Dehiscent } \\
\text { capsule }\end{array}$ & $\begin{array}{l}\text { Indehiscent } \\
\text { capsule }\end{array}$ & & & \\
\hline Muganli-57 x ACS 344 & 803 & 254 & 792.75 & 264.25 & 0.53 & $0.45-0.50$ & $3: 1$ \\
\hline
\end{tabular}


type (Table 4). The remain $\mathrm{F}_{3}$ plants sourced from offsprings 3, 6, 7 and 9 consisted of 160 dehiscent and 36 indehiscent capsule type plants, totally.
This result indicated that indehiscent and dehiscent plants fitted the expected 3:1 ratio in the offsprings of 3, 6, 7 and 9 (Table 4).

Table 4- Segregation ratios of dehiscent and indehiscent capsule characters of sesame in $F_{3}$

\begin{tabular}{lllll}
\hline Cross & Number of plants & & \\
\hline Muganli-57 x ACS 344 & $\begin{array}{l}\text { Dehiscent } \\
\text { capsule } \\
\text { plants }\end{array}$ & $\begin{array}{l}\text { Indehiscent } \\
\text { capsule } \\
\text { plants }\end{array}$ & Ratio & Symbol \\
\hline$F_{2}$ progeny with dehiscent capsule & \multicolumn{5}{l}{} \\
\hline Offspring 1 & 56 & 0 & $1: 0$ & Id/Id \\
Offspring 2 & 59 & 0 & $1: 0$ & Id/Id \\
Offspring 3 & 65 & 14 & $3: 1(\mathrm{P}=0.14)$ & Id/id \\
Offspring 4 & 35 & 0 & $1: 0$ & Id/Id \\
Offspring 5 & 13 & 0 & $1: 0$ & Id/Id \\
Offspring 6 & 24 & 6 & $3: 1(\mathrm{P}=0.52)$ & Id/id \\
Offspring 7 & 23 & 8 & $3: 1(\mathrm{P}=0.92)$ & Id/id \\
Offspring 8 & 29 & 0 & $1: 0$ & Id/Id \\
Offspring 9 & 48 & 8 & $3: 1(\mathrm{P}=0.06)$ & Id/id \\
\hline$F_{2}$ progeny with indehiscent capsule & & & \\
\hline Offspring 1 & 0 & & $0: 1$ & id/id \\
Offspring 2 & 0 & 28 & id/id \\
Offspring 3 & 0 & 25 & $0: 1$ & id/id \\
Offspring 4 & 0 & 29 & id/id \\
Offspring 5 & 0 & 63 & id/id \\
\hline
\end{tabular}

\section{Discussion}

Indehiscent capsule plants indicated low heritability for seed yield and important yield components. This result might be sourced of the mutation event because a large deletion of a chromosome segment could be occurred in development of indehiscent capsule type plants. By the deletion event, if the plants are indehiscent in $\mathrm{F}_{2}$, then the chromosome with a large deletion are paired with a normal one. Thus, the plant is indehiscent capsule type but the deleterious effect as a result of the natural mutation is still continuous in the $\mathrm{F}_{2}$ plants though different background crosses were made.

TSW of indehiscent capsule types in $F_{1}$ to $F_{2}$ and $\mathrm{F}_{2}$ to $\mathrm{F}_{3}$ had low heritability compared to dehiscent capsule types. This low heritability indicated that it would not be a close correspondence between genotype and phenotype for the mutant types due to the relative high contribution of the environment to the phenotype. Small capsules and weak seeds might also be responsible for the lower values which might effect to seed yield because seed size (Kumar 2010) and capsule length (Chowdhury et al 2010; Yol et al 2017) have strong correlations with seed yield in sesame. Similarly Hika et al (2015) obtained low heritability for TSW in dehiscent capsule type sesame plants. Only $\mathrm{PH}$ had higher mean in indehiscent capsules in $F_{2}$ compared to $F_{1}$ and parents. This positive improvement could be explained by additive gene effect because mutant crosses might have heterotic effect. Similar effects were observed by Murty (2001) and Maluszynski et al (2001) for sesame and different plants, respectively. This prediction is reasonable because similar improvement was also observed in $\mathrm{PH}$ of dehiscent capsule types in $\mathrm{F}_{2}$ and it was consistent 
with high heritability for this character as reported by Govidarasu et al (1990). In contrast to low heritability values of indehiscent capsule types, dehiscent capsules showed high heritability in $F_{1}$ to $\mathrm{F}_{2}$ and $\mathrm{F}_{2}$ to $\mathrm{F}_{3}$. NB had high genetic advance and heritability with higher mean values compared to $\mathrm{F}_{1}$. Mutant crosses therefore might have heterotic effect on character of NB which was identified as one of the most contributing character to seed yield (Yol et al 2010). Greater heritability and high genetic advance in SY of dehiscent capsules showed that this parameter was under the additive genetic effects (Mahmood et al 2004). Selection of high yield genotypes obtained from mutant $\mathrm{x}$ cultivar crosses therefore has agricultural benefit because additive effects have positive contribution to SY (Hoballah 2001). This positive effect was also observed for dehiscent capsule types in $\mathrm{F}_{2}$ compared to parents and $\mathrm{F}_{1}$. Similarly, Uzun et al (2004) reported that all hybrids showed heterosis for seed yield in mutant $\mathrm{x}$ cultivar crosses. This approach was also suggested to develop new genotypes having more than one of the desired characters using with crosses 'local varieties $\mathrm{x}$ mutants', 'mutants $\mathrm{x}$ mutants', and 'mutants x introduced lines' by Van Zanten (2001).

The cross made in current study indicated that dehiscent capsule in sesame was under the control of a single gene and dehiscent character was dominant to indehiscent capsule. Dehiscent capsule had monogenic inheritance and indehiscent capsule was controlled by a recessive allele. Firstly, Langham (1946) discovered an indehiscent mutation and this character was symbolized as $i d$ (indehiscent gene). $i d / i d$ genotype capsules were so rigid and its capsules open when it took a hammer (Langham \& Wiemers 2002). Other indehiscent capsule character was also recessive and it's called "seamless", symbolized $g s / g s$ (Langham 2001), appear to have only one carpel although it has 4 rows of seeds (Ashri 1998). Even though the single gene effect was identified, the indehiscent capsule types show deleterious characteristics such as semi-sterility, twisted stems, and low yield as a result of unwanted side-effects. In addition threshing the hard capsule without damaging the seed is too difficult (Weiss 1971). Due to undesirable characters, the $g s$ and $i d$ allele can only be used in a timely manner to minimize the effects of seed damage from threshing (Van Zanten 2001). However it does not seem a commercial. Rather than direct using of indehiscent capsule, cross breeding will be useful for development of superior varieties of sesame (Kang 2001). Because, this present study showed that "cultivar x mutant" crosses had positive effect on development of desirable genotypes.

\section{Acknowledgements}

The authors are thankful to the Scientific Research Projects Coordination Unit of Akdeniz University and the Scientific and Technological Research Council of Turkey (TUBITAK) under the project number of TOVAG 1070912 for their financial supports.

\section{References}

Ashri A (1998). Sesame breeding. Plant Breeding Reviews 16: $179-228$

Ashri A (2007). Sesame (Sesamum indicum L.). In: R J Singh (Ed.), Genetics Resources, Chromosome Engineering and Crop Improvement, Vol. 4, Oilseed Crops, CRC Press, Boca Raton, pp. 231-289

Chowdhury S, Datta A K, Saha A, Sengupta S, Paul R, Maity S \& Das A (2010). Traits influencing yield in sesame (Sesamum indicum L.) and multi locational trials of yield parameters in some desirable plant types. Indian Journal of Science and Technology 3: 163-166

Govidarasu R, Rathinam M \& Sivasubramania P (1990). Genetic variability in sesamum (Sesamum indicum L.). The Madras Agricultural Journal 78: 450-452

Hahm T S, Park S J \& Martin L Y (2009). Effects of germination on chemical composition and functional properties of sesame (Sesamum indicum L.) seeds. Bioresource Technology 100: 1643-1647

Harikumar K B, Sung B, Tharakan S T, Pandey M K, Joy B, Guha S, Krishnan S \& Aggarwal B B (2010). Sesamin manifests chemopreventive effects through suppression of NF-KB-regulated cell survival, proliferation, invasion and angiogenic gene products. Molecular Cancer Research 8: 751-761 
Hika G, Geleta N \& Jaleta Z (2015). Genetic variability, heritability and genetic advance for the phenotypic traits in sesame (Sesamum indicum L.) populations from Ethiopia. Science, Technology and Arts Research Journal 4: 20-26

Hoballah A A (2001). Selection and agronomic evaluation of induced mutant lines of sesame. In: Van Zanten L. (Ed.): Sesame Improvements by Induced Mutations, Proc. Final FAO/IAEA Co-ord. Res. Mtng. Vienna, IAEA, pp. 137-149

IPGRI \& NBPGR (2004). Descriptors for Sesame (Sesamum spp.), International Plant Genetic Resources Institute, Rome, Italy, and National Bureau of Plant Genetic Resources, New Delhi, India

Kang C W (2001). Breeding sesame for diseases and shatter resistant high yielding varieties with induced mutations. In: L Van Zanten (Ed), Sesame Improvements by Induced Mutations, Proc. Final FAO/IAEA Co-ord. Res. Meeting, IAEA, Vienna, pp. 41-49

Khan N U, Marwat K B, Hassan B, Farhatullah G, Batool S, Makhdoom K, Ahmad W \& Khan H U (2010). Genetic variation and heritability for cotton seed, fiber and oil traits in Gossypıum hirsutum L. Pakistan Journal of Botany 42: 615-625

Kumar S T (2010). Seed genetics in relation to seed yield sesame. In: D Bedigian (Ed), Sesame: The Genus Sesamum, Medicinal and Aromatic Plants-Industrial Profiles, CRC Press, Boca Raton, pp. 255-265

Langham D G (1946). Genetics of sesame, III. "Open sesame" and mottled leaf. Journal of Heredity 37: 149-152

Langham D R (2001). Shatter resistance in sesame. In: L Van Zanten (Ed), Sesame Improvements by Induced Mutations, Proc. Final FAO/IAEA Co-ord. Res. Meeting, IAEA, Vienna, pp. 51-61

Langham D R \& Wiemers T (2002). Progress in mechanizing sesame in the US through breeding. In: J Janickand \& A Whipkey (Eds), Trends in New Crops and New Uses, American Society for Horticultural Science Press, Virginia, pp. 157-173

Mahmood T, Turner M, Stoddard F L \& Javed M A (2004). Genetic analysis of quantitative traits in rice (Oryza sativa L.) exposed to salinity. Australian Journal of Agricultural Research 55: 1173-1181

Majidi M M, Mirlohi A \& Amini F (2009). Genetic variation, heritability and correlations of agromorphological traits in tall fescue (Festuca arundinacea Schreb.). Euphytica 167: 323-331
Maluszynski M, Szarejko I. Barriga P \& Balcerzyk A (2001) Heterosis in crop mutant crosses and production of high yielding lines using doubled haploid systems. Euphytica 120: 387-398

Murty G S S (2001). Induced mutants for the improvement of sesame and hybrid seed production. In: L Van Zanten (Ed), Sesame Improvements by Induced Mutations, Proc. Final FAO/IAEA Co-ord. Res. Meeting, IAEA, Vienna, pp. 99-111

Smith J D \& Kinman M L (1965). The use of parentoffspring regression as an estimator of heritability. Crop Science 5: 595-596

Steel R G D \& Torrie J H (1980). Principles and procedures of statistics: A biometrical Approach. McGraw-Hill, New York

TSMS (2010). Turkish State Meteorological Service.http:// www.dmi.gov.tr/en-US/forecast-cities.aspx?m= ANTALYA. (Access date:10.10.2015)

Uzun B, Lee D, Donini P \& Cagirgan M I (2003). Identification of a molecular marker linked to the closed capsule mutant trait in sesame using AFLP. Plant Breeding 122: 95-97

Uzun B, Ozbas M O, Canci H \& Cagirgan M I (2004). Heterosis for agronomic traits in sesame hybrids of cultivars x closed capsule mutants. Acta Agriculturae Scandinavica, Section B - Soil and Plant Science 54: 108-112

Van Zanten L (2001). Sesame improvement by induced mutations: Results of the co-ordinated research project and recommendation for future studies. In: $\mathrm{L}$ Van Zanten (Ed), Sesame Improvements by Induced Mutations, Proc. Final FAO/IAEA Co-ord. Res. Meeting, IAEA, Vienna, pp. 1-12

Weiss E A (1971). Castor, sesame and safflower. Barnes and Noble Inc, New York

Wongyai W, Saengkaewsook W \& Veerawudh J (2001). Sesame mutation induction: improvement of nonshattering capsule by using gamma rays and EMS. In: L Van Zanten (Ed), Sesame Improvements by Induced Mutations, Proc. Final FAO/IAEA Co-ord. Res. Meeting, IAEA, Vienna, pp. 71-78

Yol E, Karaman E, Furat S \& Uzun B (2010). Assessment of selection criteria in sesame by using correlation coefficients, path and factor analyses. Australian Journal of Crop Science 4: 598-602

Yol E, Toker C \& Uzun B (2017). Inheritance of long and dense capsule characteristics in sesame. Turkish Journal of Field Crops 22: 8-13 